\title{
International Monetary Policy Coordination through Communication: Chasing the Loch Ness Monster*
}

\author{
Serkan Imisiker ${ }^{\mathrm{a}}$ and Bedri Kamil Onur Tas ${ }^{\mathrm{b}}$ \\ ${ }^{a}$ Independent Researcher \\ ${ }^{\mathrm{b}}$ TOBB University of Economics and Technology
}

\begin{abstract}
We empirically examine international monetary policy coordination. We use the Global Economy Meetings (GEMs) at the Bank for International Settlements (BIS) to design a novel empirical identification strategy. We find that communication between the central bank governors at the BIS GEMs promotes policy coordination.
\end{abstract}

JEL Codes: E52, E58.

\section{Introduction}

International monetary coordination has become a major policy argument since the global financial crisis. However, there is little evidence of coordination among central banks. Blanchard, Ostry, and Gosh (2013) even call policy coordination "the Loch Ness monster: much discussed but rarely seen." In this paper, we chase the Loch Ness monster and empirically examine the existence of international monetary policy coordination.

Although various studies report significant spillover from the Federal Reserve's monetary policy actions to its counterparts (e.g., Edwards 2015 and Hofmann and Takáts 2015), empirical evidence about the existence of monetary coordination does not exist in the

${ }^{*}$ We would like to thank Kaushik Jayaram, Michalis Ghalanos, and an anonymous referee for extremely helpful comments. Corresponding author (Onur Tas): TOBB University of Economics and Technology, Department of Economics, Sogutozu Cad. No. 43, 06530 Sogutozu, Ankara, Turkey. E-mail: onurtas@etu.edu.tr. 
literature. In this paper, we use the Bank for International Settlements (BIS) meetings to identify coordination empirically. We investigate whether the increased means of communication between governors of central banks have any effect on the correlation of monetary policy decisions.

Borio and Toniolo (2006) classify central bank cooperation in two categories. "Low-key" cooperation expresses the exchange of information between central banks, whereas "high-profile" cooperation is about joint actions. Throughout the history of central banking, the former type of cooperation becomes evident, especially after the establishment of the BIS. The latter is mostly seen in the wake of large-scale financial turbulences 11 Bernanke (2014) mentions the importance of the BIS meetings. He states that "the Fed Chairman or Vice Chairman meets with emerging market governors at least eight to ten times a year, for an hour or more, at the BIS and other contacts, to explain policy and to hear comments. So, there's an awful lot of consultation."

The BIS is the foremost venue for central bank cooperation. It is a crucial ground for central bankers to share their experiences on common problems. The BIS, regarded as a genuine meeting point of central bankers from its sixty members, organizes regular meetings for the high-level representatives of central banks. Among these gatherings, the bimonthly Global Economy Meeting (GEM) that brings together the governors of major monetary authorities is one of the significant events. Former President of the European Central Bank Jean-Claude Trichet emphasizes the importance of GEMs as the following 2

In the area of central bank cooperation, the main forum is the Global Economy Meeting (GEM) ... The GEM, in which all systemic emerging economies' Central Bank governors are fully participating, has become the prime group for global governance

\footnotetext{
${ }^{1}$ Joint actions of the central banks of Bank of Canada, the Bank of England, the European Central Bank, the Federal Reserve, Sveriges Riksbank, and the Swiss National Bank on October 8, 2008 can be given as an example of "high-profile" cooperation of central banks.

2Jean-Claude Trichet, "Global Governance Today" (keynote address, Council on Foreign Relations, New York, April 26, 2010). Available at http://www.bis. org/review/r100428b.pdf.
} 
among central banks. The GEM has become a very important forum for assessing global economic and financial conditions, for analyzing economic and financial policy issues of common interest to central banks.... I find the candid exchange of views of our bi-monthly meetings of enormous value.

Following these arguments, we conduct several empirical analyses to investigate whether monetary policy decisions of the central banks where the governor participates in the GEM are more synchronized than those of outsiders. Using different econometric specifications, we find that GEM participants have significantly higher correlation of monetary policy actions, a sign of greater coordination.

\section{Data and Methodology}

Starting with the 2009 Annual Report, the BIS announces the list of countries from which the central bank governors participate in the GEM 3 There are two categories for the participant countries, namely members and observers. Governors from thirty-one central banks attend the meeting as members of the GEM. The number of observer central banks is seventeen until 2012 and nineteen afterwards. Central banks of Colombia and Peru are the latecomers to the observer list. We collect the list of the countries by reading the BIS Annual Reports. We consider both the attendants and observers as GEM participants since all the governors are present at the meetings and have full access to the means of communication at the GEM 4 We eliminate the countries with currency board and

\footnotetext{
${ }^{3}$ As stated by the 2014 BIS Annual Report, "The members of the GEM are the central bank Governors of Argentina, Australia, Belgium, Brazil, Canada, China, France, Germany, Hong Kong SAR, India, Indonesia, Italy, Japan, Korea, Malaysia, Mexico, the Netherlands, Poland, Russia, Saudi Arabia, Singapore, South Africa, Spain, Sweden, Switzerland, Thailand, Turkey, the United Kingdom, and the United States and also the President of the European Central Bank and the President of the Federal Reserve Bank of New York. The Governors attending as observers are from Algeria, Austria, Chile, Colombia, the Czech Republic, Denmark, Finland, Greece, Hungary, Ireland, Israel, Luxembourg, New Zealand, Norway, Peru, the Philippines, Portugal, Romania, and the United Arab Emirates."

${ }^{4}$ We also conduct the regression analysis using separate variables for attendants and observers. The results are not affected by this alternative specification. The alternative estimation results are available from the authors upon request.
} 
conventional peg exchange rate regimes as listed in the "Annual Report on Exchange Arrangements and Exchange Restrictions" (AREAER) of the International Monetary Fund (IMF) 5 After removing the national central banks in the euro zone 6 we have fiftythree central banks in our data set that includes twenty-one members and eight observers (ten after 2012) of the GEM 7 We display the list of countries in table 7 in the appendix.

We measure the cross-country coherences of monetary policy by computing the Pearson's correlation coefficients (PCCs) of the cyclical components of the money market rate 8 We follow Aizenman, Chinn, and Ito (2008) and employ money market rates extracted from the IMF International Financial Statistics (IFS) database to assess monetary policy. We calculate the cyclical components using the Hodrick-Prescott filter following Vegh and Vuletin (2012). Studies like Flood and Rose (2010) use the PCC to assess the timevarying relationship between cyclical components of macroeconomic variables.

We calculate the PCCs using twenty-four monthly observations using the following specification:

$$
\rho_{a, b, \tau}=\frac{1}{T-1} \sum_{t=1}^{\tau}\left(\frac{i_{a, t}^{d}-i_{a, \tau}^{d}}{i_{a, \tau}^{d}}\right)\left(\frac{i_{b, t}^{d}-i_{b, \tau}^{d}}{i_{b, \tau}^{d}}\right) .
$$

$\rho_{a, b, \tau}$ is the sample correlation coefficient estimated between the cyclical components of money market rates $(i)$ for countries $a$ and

\footnotetext{
${ }^{5}$ The AREAERs are available at http://www.elibrary-areaer.imf.org/Pages/ Home.aspx. The most notable central banks that we drop are Bahrain, Bulgaria, Denmark, Hong Kong SAR, Jordan, Morocco, Oman, Qatar, Saudi Arabia, United Arab Emirates, and Venezuela, among others. We have conducted the empirical analysis using an extended data set of seventy-one central banks. We obtain similar results. The results with the extended data set are available from the authors upon request.

${ }^{6}$ Belgium, France, Germany, Italy, the Netherlands, and Spain are GEM attendants that are European Economic and Monetary Union (EMU) countries. Austria, Finland, Greece, Ireland, Luxembourg, and Portugal are EMU countries that are GEM observers. Latvia became a member of the EMU on January 1, 2014. Before adopting the euro, Latvia implemented a conventional peg exchange rate regime.

${ }^{7}$ Money market rate is missing for Algeria and China for certain months.

${ }^{8}$ We employ the central bank average funding rate for the Central Bank of Turkey as suggested by Kara (2015).
} 
$b$ over the twenty-four $(T)$ months preceding through time $\tau$. We compute this statistic between pairs of countries over time and use it as the key measure of monetary policy coordination. This measure allows us to assess the time-varying structure of monetary policy synchronization. We calculate the PCCs of country pairs for April 2009-September 2014. We use the cyclical components of money market rates since interest rates of developed countries share a common trend which might superficially increase the PCCs. We conduct several robustness analyses by employing alternative measures of changes in monetary policy in section 4 .

Figure 1 displays the histogram of the PCC among different country pairs.

We estimate the following regression specification of Flood and Rose (2010) to examine the impact of increased means of communication at the BIS meetings on monetary policy co-movement:

$$
\begin{aligned}
\rho_{a, b, \tau}= & \beta_{0}+\beta_{1} \text { Both } B I_{a, b, \tau}+\beta_{2} \text { Both } \text { Advanced }_{a, b, \tau} \\
& +B \theta_{\tau}+\varepsilon_{a, b, \tau} .
\end{aligned}
$$

Both $B I S$ is a dummy variable that is unity if both countries $a$ and $b$ attend the BIS GEM meetings; Both Advanced is a dummy variable for correlation between advanced countries; $\theta_{\tau}$ contains the time-varying control variables that are the cyclical component of the shadow policy rate of the Federal Reserve (Wu and Xia 2016), the VIX index, the minimum of the financial openness index of countries $a$ and $b 9$ and a measure of business cycle synchronization. We gauge business cycle synchronization of countries $a$ and $b$ by calculating PCCs of cyclical components of real GDP of country pairs, $\rho_{a, b, \tau}^{b c}$, as in Flood and Rose (2010). The business cycle synchronization measure, $\rho_{a, b, \tau}^{b c}$, is the sample correlation coefficient estimated between the cyclical components of real GDP for countries $a$ and $b$ over the twenty-four $(T)$ months preceding through time $\tau$ as described in equation (11).

The VIX index contains essential information about global capital flows. Rey (2015, p. 1) finds that "there is a global financial

${ }^{9}$ We employ the index produced by Chinn and Ito (2006). The index is available for years 1970-2014 for 182 countries. 


\section{Figure 1. Histogram of the Time-Varying Correlation Measure}
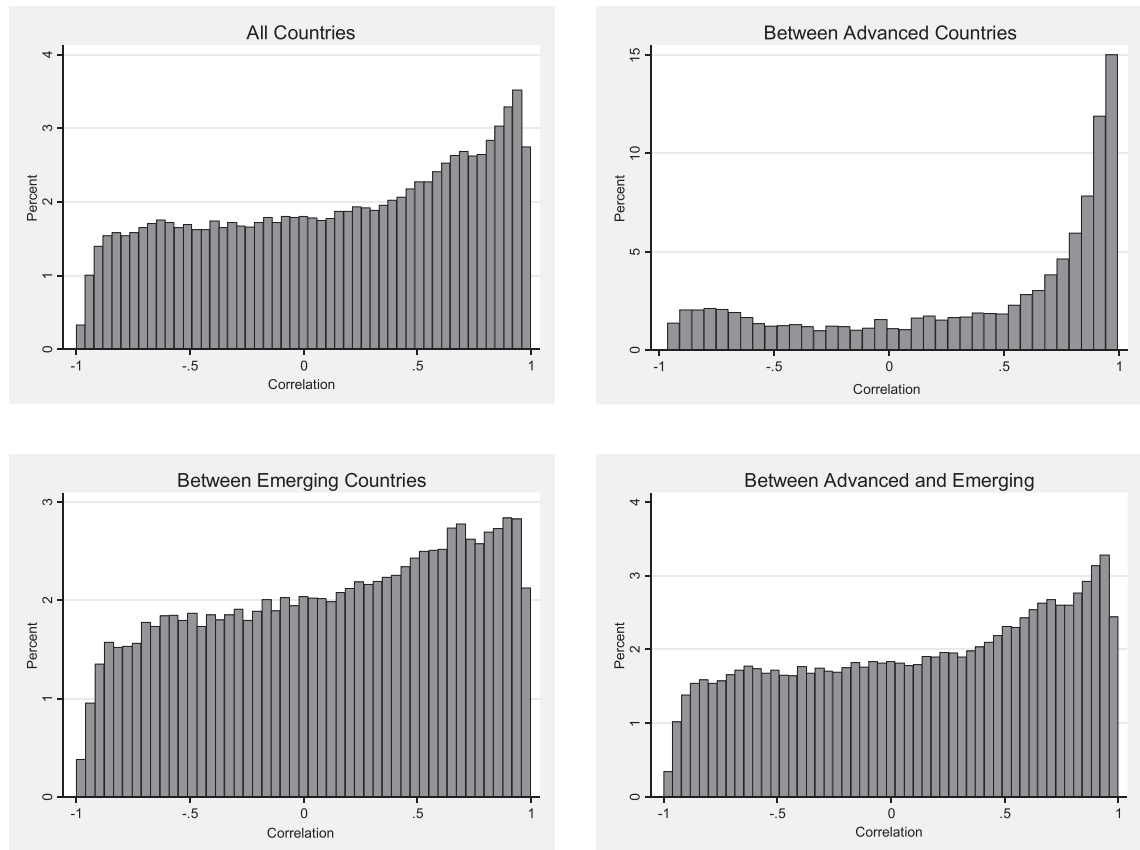

cycle in capital flows, assets prices and in credit growth." She concludes that the VIX is closely related to the global capital flows. Therefore, we control for global capital flows that might significantly affect interest rates by employing the VIX index as a control variable. Furthermore, VAR analysis conducted by Rey (2015) concludes that U.S. monetary policy is one of the major determinants of the global financial cycle. Accordingly, we use the shadow policy rate of the Fed to control for the changes in the U.S. monetary policy. We estimate equation (2) using the random-effects estimator with Huber-White robust standard errors. We also employ month fixed effects.

Additionally, we consider that membership to the GEM might be endogenous. We employ an instrumental-variable (IV) estimation approach. We instrument for the Both $B I S_{a, b, \tau}$ variable and estimate the coefficients of equation (2) using an IV GMM methodology. 
We implement the heteroskedasticity-based instrumental-variable (HB-IV) methodology developed by Lewbel (2012). The methodology provides an unbiased and consistent estimate of the parameters when the regression model contains endogenous or mismeasured regressors, or when the model suffers from the omitted-variable bias. Monte Carlo study results and numerous empirical applications presented in Lewbel (2012) show that the estimator works well compared with two-stage least squares and GMM when valid instrumental variables are not available 10 The methodology of Lewbel (2012) uses the heteroskedasticity of the errors to achieve identification through observing a vector of regressor variables uncorrelated with the covariance of heteroskedastic errors.

We use HB-IV since it does not require predetermined instrumental variables to produce unbiased and consistent estimates of the parameters. We do not determine the instrumental variables in the HB-IV methodology. Instead, the method builds valid IVs (uncorrelated with the error term) using the heteroskedasticity structure of the error terms and employs these valid IVs to conduct IV GMM estimation. Accordingly, HB-IV allows us to examine the soundness of the panel estimation results.

\section{Empirical Analysis}

We gauge the existence and level of coordination among central banks by estimating the impact of means of communication at the BIS meetings on time-varying correlation of cyclical components of monetary policy actions of fifty-three central banks. Table 1 shows the coefficients of equation (2) estimated using both random-effects panel regression and HB-IV GMM. The coefficient of the Both BIS dummy variable, $\beta_{1}$, measures the impact of communication at the BIS GEM.

The coefficient of the Both BIS dummy variable is significant, with a positive coefficient indicating that central banks that

\footnotetext{
${ }^{10}$ Lewbel (2012, p. 77$)$ states that "the proposed estimators appear to work well in both a small Monte Carlo study ... and in an empirical application. Citing working paper versions of the present article, some articles by other researchers listed earlier include empirical applications of the proposed estimators and find them to work well in practice."
} 


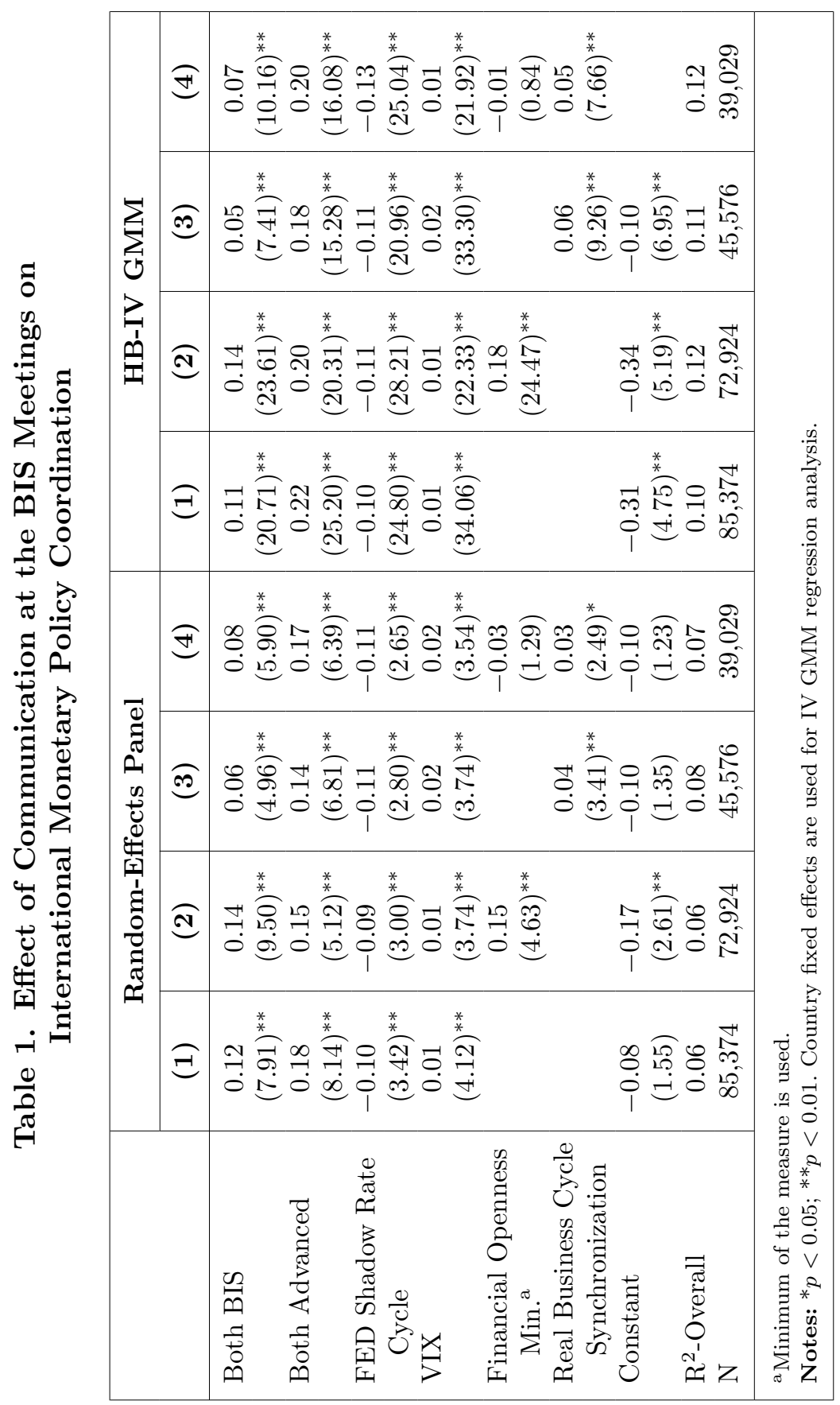


attend the GEM have significantly higher levels of coordination. We also conclude that the co-movement of monetary policies among advanced country pairs is significantly higher than that of other pairs.

\section{Robustness Analysis}

In this section, we conduct several additional analyses to validate the robustness of our results.

\subsection{Time-Series Analysis}

Colombia and Peru started to attend the GEM in 2012. This feature allows us to conduct a robustness analysis by examining structural changes in the correlation between other GEM attending countries and Colombia and Peru. We investigate whether the monetary policy coordination between GEM countries and Colombia and Peru is different after April 2012 when the central bank governors of Colombia and Peru started to attend the GEM meetings. Table 2 displays the estimation results of the following regression equation:

$$
\rho_{G E M, \tau}^{\text {Colombia,Peru }}=\beta_{0}+\beta_{1} \text { Become } \text { Member }_{\tau}+B \theta_{\tau}+\varepsilon_{G E M, \tau} .
$$

\section{Table 2. Time-Series Analysis with Colombia and Peru}

\begin{tabular}{|l|c|}
\hline Become Member & 0.25 \\
Federal Reserve Shadow Rate Cycle & $(2.63)^{* *}$ \\
& -0.56 \\
VIX & $(10.30)^{* *}$ \\
& 0.02 \\
Financial Openness Min. & $(3.82)^{* *}$ \\
& -0.11 \\
Constant & $(3.79)^{* *}$ \\
& -0.14 \\
$\mathrm{R}^{2}$ & $(1.40)$ \\
$\mathrm{N}$ & 0.18 \\
\hline Note: ${ }^{*} p<0.05 ;{ }^{* *} p<0.01$. & 2,622 \\
\hline
\end{tabular}


$\rho_{G E M, \tau}^{C o l o m b i a, P e r u}$ is the time-varying PCC of Colombia and Peru with other GEM countries. Become Member $_{\tau}$ is the dummy variable which is one after April 2012. Table 2 shows that the correlation of monetary policy actions between GEM participants and Colombia and Peru increased significantly after April 2012 when Colombia and Peru started to attend the GEM meetings.

The significant and positive coefficient of Become Member $_{\tau}$ confirms the main result presented in table 1 using a different regression specification. Monetary policy actions of Colombia and Peru significantly became more synchronized with other GEM attendees after they started to attend the meetings and had access to higher means of communication with other GEM central bankers.

\subsection{Using Extended Data until 2003}

We conduct an additional robustness analysis by extending the data set. The BIS Annual Reports disclose the GEM participants since 2009. We contacted the officials at the BIS about the list of GEM members before 2009. The officials at the BIS stated that the list of member countries did not change since 2003. They did not provide further information about the GEM attendants before 2003. Therefore, we estimate the coefficients of equation (2) by employing a data set that starts from April 2003. A major drawback of the extended data set is that interest rate is available only for fortythree countries - twenty-nine GEM members and fourteen non-GEM countries. Table 3 displays the panel and HB-IV GMM estimation results.

The coefficient of the Both BIS dummy variable is significant, with a positive coefficient indicating that central banks that attend the GEM have significantly higher levels of coordination. We also conclude that the co-movement of monetary policies among advanced country pairs is significantly higher than that of other pairs for the extended sample period.

\subsection{Measuring Monetary Policy Using First Differences of Money Market Rates}

Several studies like Kuttner (2001) and Bernanke and Kuttner (2005) employ the first difference of the monthly federal funds rate 


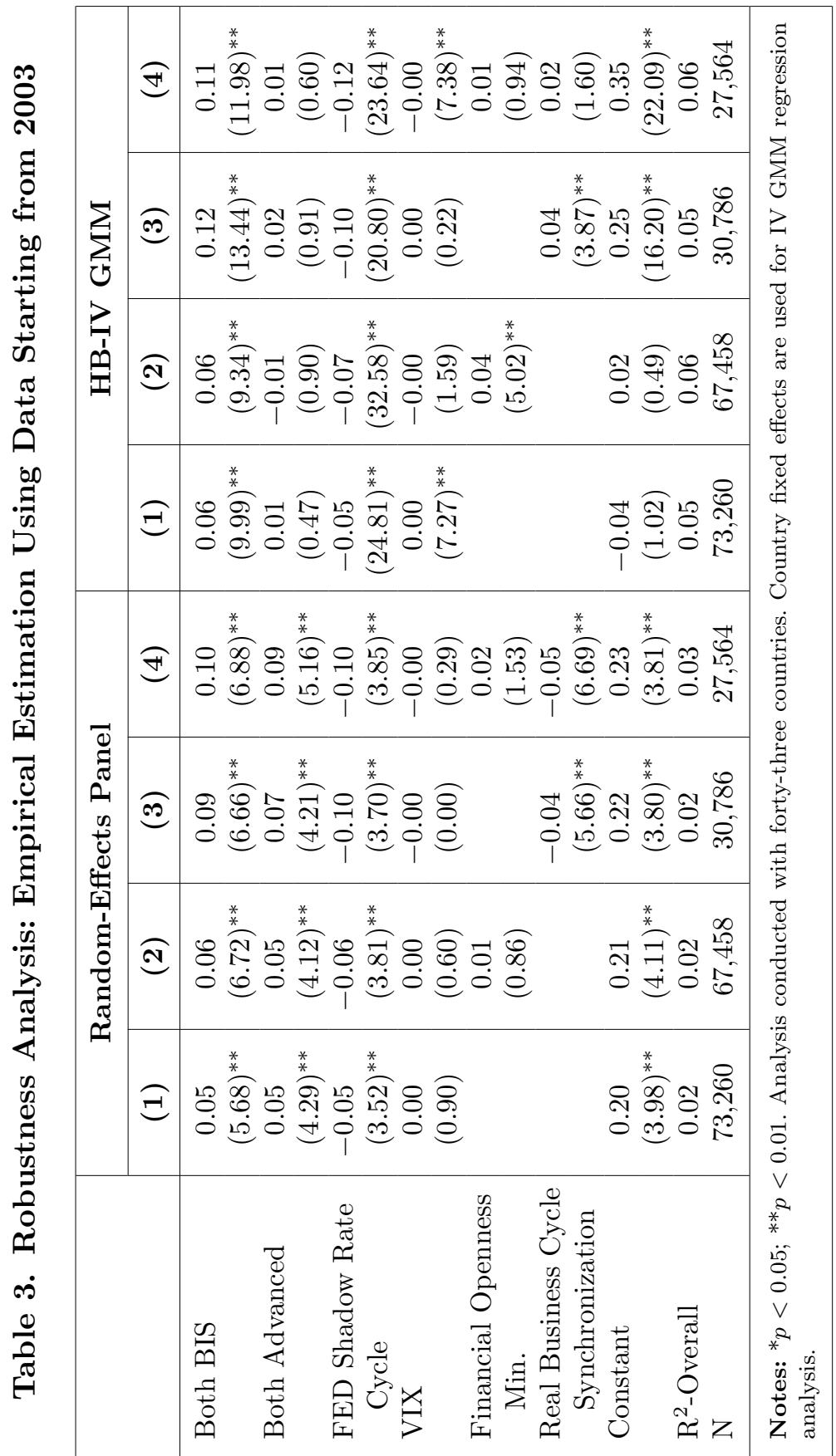


to gauge the changes in monetary policy. Accordingly, we conduct an additional robustness analysis and calculate correlation coefficients between first differences of money market rates of country pairs to assess the level of monetary policy coordination. We use this alternative coordination measure, $\rho_{a, b, \tau}^{\text {first }}$ dif , as the dependent variable in our main regression specification presented in equation (2). Table 4 shows the results.

Table 4 validates the main results of the paper presented in table 1. The coefficient of the Both BIS dummy variable is significant, with a positive coefficient indicating that central banks that attend the GEM have significantly higher levels of coordination. Both random-effects and HB-IV estimations produce similar results.

\subsection{Floating Exchange Rate Regime Countries}

We conduct additional robustness analysis by focusing on thirtyseven countries with floating exchange rate regimes as listed in AREAERs of the IMF. Among thirty-seven countries, seventeen are GEM attendants, ten are GEM observers, and ten countries do not attend the GEM 11 Table 5 displays the panel and HB-IV GMM estimation results for floating exchange rate regime countries.

The coefficient of the Both BIS dummy variable is significant, with a positive coefficient indicating that central banks that attend the GEM have significantly higher levels of coordination. We also conclude that the co-movement of monetary policies among advanced country pairs is significantly higher than that of other pairs for floating exchange rate regime countries.

\subsection{Principal Component Analysis}

Our final robustness analysis uses principal component analysis and examines whether common factors of interest rates change with GEM participation. We follow studies like Kritzman et al. (2011)

\footnotetext{
${ }^{11}$ We display countries with floating exchange rate regimes in table 8 in the appendix.
} 


\begin{tabular}{|c|c|c|c|}
\hline \multirow{3}{*}{$\begin{array}{l}\sum_{i=1}^{2} \\
0 \\
0 \\
1\end{array}$} & $\bar{x}$ & 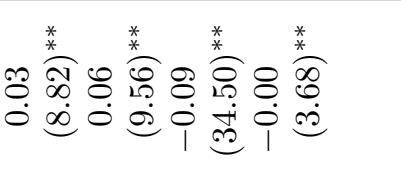 & 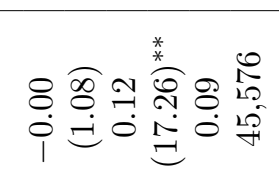 \\
\hline & $\overline{\mathbf{y}}$ & 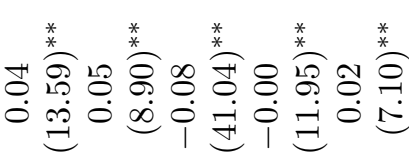 & 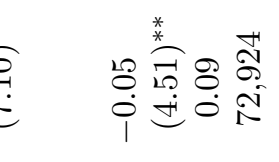 \\
\hline & $\hat{E}$ & 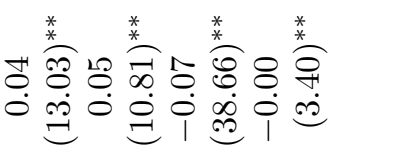 & il \\
\hline \multirow{4}{*}{ 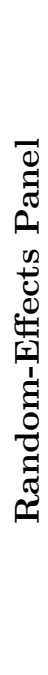 } & $\mathbb{E}$ & \multicolumn{2}{|c|}{ 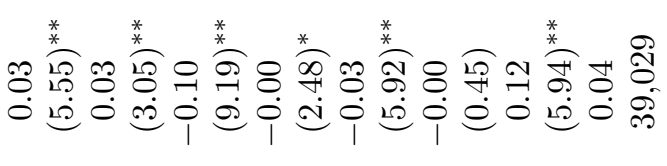 } \\
\hline & $\sqrt{20}$ & 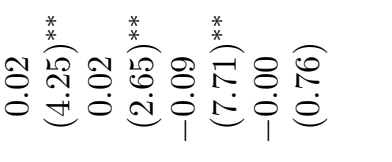 & 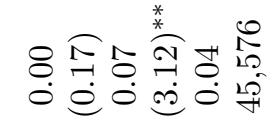 \\
\hline & $\widehat{\widehat{y}}$ & 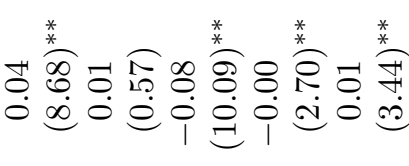 & 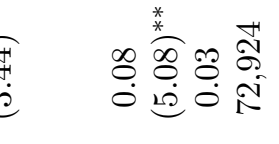 \\
\hline & $\Xi$ & 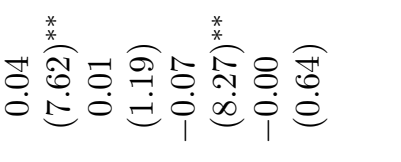 & 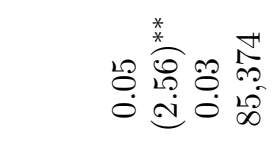 \\
\hline & & 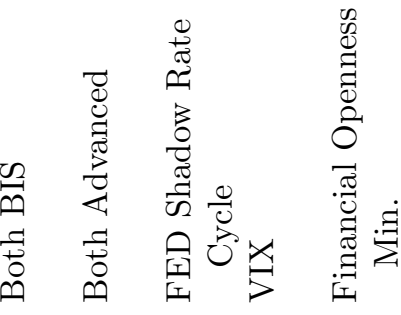 & 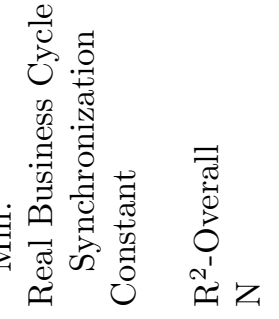 \\
\hline
\end{tabular}




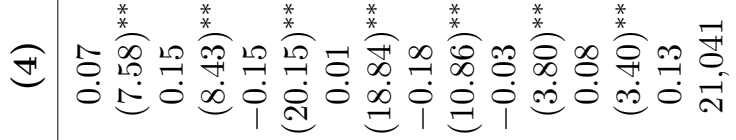

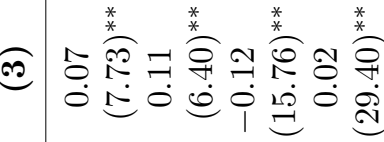

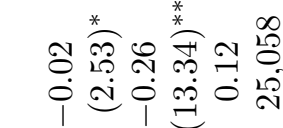

Iี

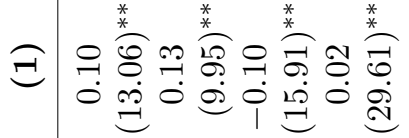

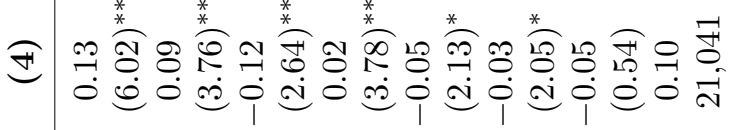

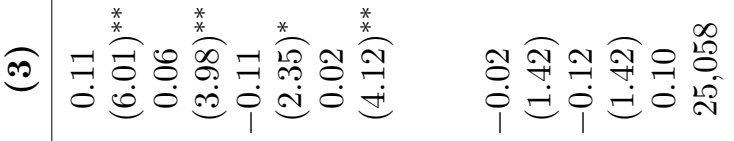

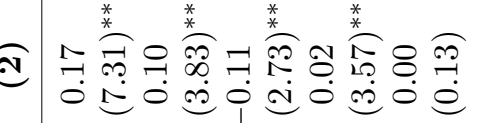

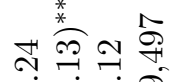

$$
\begin{aligned}
& \text { ○ं }
\end{aligned}
$$

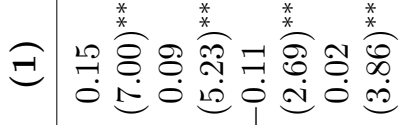




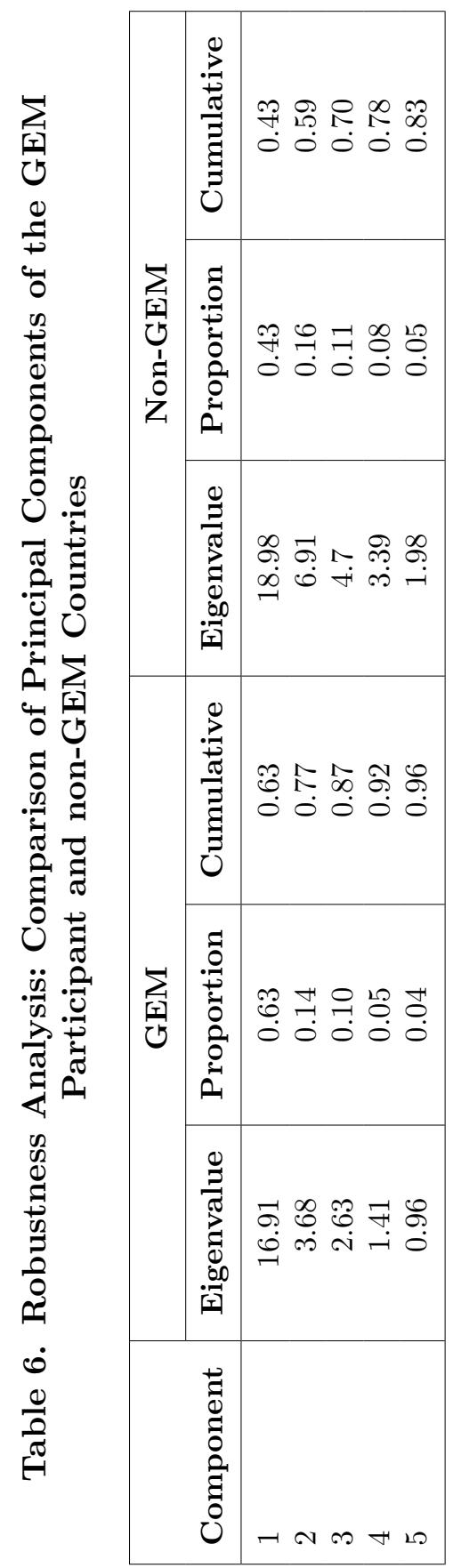


and Eichengreen et al. (2012) 12 and calculate principal components of money market rates of the GEM participant and non-GEM countries separately. We compare the variance accounted for by principal components for both GEM participant and non-GEM money market rates. See table 6 .

Kritzman et al. (2011) uses total variance of asset returns explained by a fixed number of principal components to measure the extent that financial markets are "tightly coupled." We compare the percentage of variation explained by the first five principal components. Table 5 shows that the first five principal components account for 96 percent of variation of the GEM participants and 83 percent of non-GEM countries. Similarly, the first principal component explains 63 percent and 43 percent of the GEM and non-GEM money market rate variation. Accordingly, we conclude that rates of GEM participants are more connected than those of non-GEM participants.

\section{Conclusion}

We examine the existence and level of international monetary policy coordination using a novel identification specification. We investigate whether communication at the BIS GEM increases co-movement of policy actions of the central banks. We conclude that monetary policy actions of central banks where the governor attends the GEM are significantly more correlated. Hence, communication at the BIS promotes policy coordination. Additionally, we show that monetary policy actions of Colombia and Peru became significantly more correlated with other GEM members after they started to attend the meetings. We conduct several robustness analyses by using an extended data set, employing an alternative monetary policy measure, focusing on floating exchange rate regime countries, and implementing principal component analysis. These analyses confirm the robustness of our results.

\footnotetext{
${ }^{12}$ Eichengreen et al. (2012) use principal component analysis to extract the common factors underlying weekly variations in the credit default swap spreads of forty-five European and U.S. banks.
} 


\section{Appendix}

\section{Table 7. List of Countries}

\begin{tabular}{|c|c|}
\hline Country & $\begin{array}{c}\text { BIS GEM } \\
\text { Membership }\end{array}$ \\
\hline Angola & Non-GEM \\
\hline Argentina & GEM Attendant \\
\hline Armenia & Non-GEM \\
\hline Australia & GEM Attendant \\
\hline Bolivia & Non-GEM \\
\hline Brazil & GEM Attendant \\
\hline Canada & GEM Attendant \\
\hline Chile & GEM Observer \\
\hline Colombia & GEM Observer \\
\hline Congo, Dem. Rep. of & Non-GEM \\
\hline Croatia & Non-GEM \\
\hline Czech Republic & GEM Observer \\
\hline Dominican Republic & Non-GEM \\
\hline Euro Area & GEM Attendant \\
\hline Georgia & Non-GEM \\
\hline Hungary & GEM Observer \\
\hline Iceland & Non-GEM \\
\hline India & GEM Attendant \\
\hline Indonesia & GEM Attendant \\
\hline Israel & GEM Observer \\
\hline Jamaica & Non-GEM \\
\hline Japan & GEM Attendant \\
\hline Korea, Republic of & GEM Attendant \\
\hline Malaysia & GEM Attendant \\
\hline Mauritius & Non-GEM \\
\hline Mexico & GEM Attendant \\
\hline Moldova & Non-GEM \\
\hline Mozambique & Non-GEM \\
\hline New Zealand & GEM Observer \\
\hline Norway & GEM Observer \\
\hline Pakistan & Non-GEM \\
\hline Papua New Guinea & Non-GEM \\
\hline Paraguay & Non-GEM \\
\hline Peru & GEM Observer \\
\hline Philippines & GEM Observer \\
\hline Poland & GEM Attendant \\
\hline Romania & GEM Observer \\
\hline
\end{tabular}


Table 7. (Continued)

\begin{tabular}{|c|c|}
\hline Country & $\begin{array}{c}\text { BIS GEM } \\
\text { Membership }\end{array}$ \\
\hline $\begin{array}{l}\text { Russian Federation } \\
\text { Serbia, Republic of } \\
\text { Singapore } \\
\text { South Africa } \\
\text { Sri Lanka } \\
\text { Sweden } \\
\text { Switzerland } \\
\text { Tajikistan } \\
\text { Thailand } \\
\text { Tunisia } \\
\text { Turkey } \\
\text { Ukraine } \\
\text { United Kingdom } \\
\text { United States } \\
\text { Uruguay } \\
\text { Vanuatu }\end{array}$ & $\begin{array}{l}\text { GEM Attendant } \\
\text { Non-GEM } \\
\text { GEM Attendant } \\
\text { GEM Attendant } \\
\text { Non-GEM } \\
\text { GEM Attendant } \\
\text { GEM Attendant } \\
\text { Non-GEM } \\
\text { GEM Attendant } \\
\text { Non-GEM } \\
\text { GEM Attendant } \\
\text { Non-GEM } \\
\text { GEM Attendant } \\
\text { GEM Attendant } \\
\text { Non-GEM } \\
\text { Non-GEM }\end{array}$ \\
\hline
\end{tabular}




\section{Table 8. Floating Exchange Rate Regime Countries}

\begin{tabular}{|c|c|c|}
\hline Country & $\begin{array}{l}\text { BIS GEM } \\
\text { Membership }\end{array}$ & $\begin{array}{l}\text { Notes about Exchange } \\
\text { Rate Regime }\end{array}$ \\
\hline Armenia & Non-GEM & $\begin{array}{l}\text { Armenia moved to crawl-like } \\
\text { arrangement from floating } \\
\text { arrangement in April } 2013 .\end{array}$ \\
\hline Australia & GEM Attendant & \\
\hline Brazil & GEM Attendant & \\
\hline Canada & GEM Attendant & \\
\hline Chile & GEM Observer & \\
\hline Colombia & GEM Observer & \\
\hline Congo, Dem. Rep. of & Non-GEM & $\begin{array}{l}\text { Democratic Republic of the Congo } \\
\text { moved to other managed arrangement } \\
\text { in November } 2011 \text {. }\end{array}$ \\
\hline Czech Republic & GEM Observer & $\begin{array}{l}\text { Czech Republic moved to other } \\
\text { managed arrangement in November } \\
2013 \text {. }\end{array}$ \\
\hline Euro Area & GEM Attendant & \\
\hline Georgia & GEM Attendant & $\begin{array}{l}\text { Georgia adopted a floating exchange } \\
\text { rate regime in years 2010, 2011, 2013, } \\
\text { and } 2014 .\end{array}$ \\
\hline Hungary & GEM Observer & \\
\hline Iceland & Non-GEM & \\
\hline India & GEM Attendant & \\
\hline Indonesia & GEM Attendant & $\begin{array}{l}\text { Indonesia adopted a crawl-like regime in } \\
\text { the July } 2012-\text { August } 2013 \text { period. }\end{array}$ \\
\hline Israel & GEM Observer & \\
\hline Japan & GEM Attendant & \\
\hline Korea, Republic of & GEM Attendant & \\
\hline Mauritius & Non-GEM & \\
\hline Mexico & GEM Attendant & \\
\hline Moldova & Non-GEM & \\
\hline Mozambique & Non-GEM & \\
\hline New Zealand & GEM Observer & \\
\hline Norway & GEM Observer & \\
\hline Papua New Guinea & Non-GEM & \\
\hline Paraguay & Non-GEM & $\begin{array}{l}\text { Paraguay implemented other managed } \\
\text { arrangement regime in years } 2010-12 \text {. }\end{array}$ \\
\hline Peru & GEM Observer & \\
\hline Philippines & GEM Observer & \\
\hline Poland & GEM Attendant & \\
\hline Romania & GEM Observer & \\
\hline Serbia, Republic of & Non-GEM & \\
\hline South Africa & GEM Attendant & \\
\hline Sweden & GEM Attendant & \\
\hline Thailand & GEM Attendant & \\
\hline Turkey & GEM Attendant & \\
\hline United Kingdom & GEM Attendant & \\
\hline United States & GEM Attendant & \\
\hline Uruguay & Non-GEM & \\
\hline
\end{tabular}




\section{References}

Aizenman, J., M. D. Chinn, and H. Ito. 2008. "Assessing the Emerging Global Financial Architecture: Measuring the Trilemma's Configurations over Time." NBER Working Paper No. 14533.

Bernanke, B. S. 2014. "Global Monetary Policy: A View from Emerging Markets." The Brookings Institution. Available at http://www.brookings.edu/events/2014/04/10-globalmonetary-policy-view-from-emerging-markets.

Bernanke, B. S., and K. N. Kuttner. 2005. "What Explains the Stock Market's Reaction to Federal Reserve Policy?" Journal of Finance 60 (3): 1221-57.

Blanchard, O., J. D. Ostry, and A. R. Gosh. 2013. "International Policy Coordination: The Loch Ness Monster." IMFDirect Blog, December 15.

Borio, C. E. V., and G. Toniolo. 2006. "One Hundred and Thirty Years of Central Bank Cooperation: A BIS Perspective." BIS Working Paper No. 197.

Chinn, M. D., and H. Ito. 2006. "What Matters for Financial Development? Capital Controls, Institutions, and Interactions." Journal of Development Economics 81 (1): 163-92.

Edwards, S. 2015. "Monetary Policy Independence under Flexible Exchange Rates: An Illusion?" The World Economy 38 (5): 77387.

Eichengreen, B., A. Mody, M. Nedeljkovic, and L. Sarno. 2012. "How the Subprime Crisis Went Global: Evidence from Bank Credit Default Swap Spreads." Journal of International Money and Finance 31 (5): 1299-1318.

Flood, R. P., and A. K. Rose. 2010. "Inflation Targeting and Business Cycle Synchronization." Journal of International Money and Finance 29 (4): 704-27.

Hofmann, B., and E. Takáts. 2015. "International Monetary Spillovers." BIS Quarterly Review (September): 105-18.

Kara, A. H. 2015. "Interest Rate Corridor and the Monetary Policy Stance." Research Notes in Economics No. 1513, Research and Monetary Policy Department, Central Bank of the Republic of Turkey. 
Kritzman, M., Y. Li, S. Page, and R. Rigobon. 2011. "Principal Components as a Measure of Systemic Risk." Journal of Portfolio Management 37 (4): 112-26.

Kuttner, K. N. 2001. "Monetary Policy Surprises and Interest Rates: Evidence from the Fed Funds Futures Market." Journal of Monetary Economics 47 (3): 523-44.

Lewbel, A. 2012. "Using Heteroscedasticity to Identify and Estimate Mismeasured and Endogenous Regressor Models." Journal of Business and Economic Statistics 30 (1): 67-80.

Rey, H. 2015. "Dilemma not Trilemma: The Global Financial Cycle and Monetary Policy Independence." NBER Working Paper No. 21162 .

Vegh, C. A., and G. Vuletin. 2012. "Overcoming the Fear of Free Falling: Monetary Policy Graduation in Emerging Markets." NBER Working Paper No. 18175.

Wu, J. C., and F. D. Xia. 2016. "Measuring the Macroeconomic Impact of Monetary Policy at the Zero Lower Bound." Journal of Money, Credit and Banking 48 (2-3): 253-91. 